\author{
A.N. Dyuryagina, A.A. Lutsenko \\ M. Kozybaev North Kazakhstan State University, Petropavlovsk, Kazakhstan \\ (E-mail: l-a.13@mail.ru)
}

\title{
Study of paint and varnishes systems structuring in the presence of surfactants
}

\begin{abstract}
Introduction of surfactants in paintwork materials composition is one of the effective ways to improve their quality. It is obvious that introduction of surface-active additives in coating compositions changes not only the dispersity of the pigments and fillers included into the composition, but also the nature of the adsorption and intermolecular interactions in the system. With the help of low-frequency dielectrometry, a physical grid of intermolecular bonds was detected in the process of its formation. The regularities of the structurization of amines and polyphenylsiloxane in solutions of toluene were established by viscosimetric method. According to the results of viscosimetric analysis, the regularities of surface tension change for polyphenylsiloxane solutions were revealed: as the concentration increases from 0 to $2 \mathrm{~g} / \mathrm{dm}^{3}$, the surface tension decreases from 28 to $26 \mathrm{~mJ} / \mathrm{m}^{2}$. Rheological data showed that deviations from the ideal system exist in the region of the studied concentrations, i.e., there is an association of molecules of the amino derivatives with macromolecules of polyphenylsiloxane (heteroassociation). It is proved that formation of macromolecular structures is inherent in all three varieties of amines and is substantially enhanced in concentrated solutions.
\end{abstract}

Keywords: organosilicon paint and varnishes, intermolecular interactions, viscosimetry, dielectrometry, toluene, additive, amines, polyphenylsiloxane, relative viscosity, surface tension.

\section{Introduction}

Organosilicon (silicone) paint and varnishes historically occupy a significant share of the paint and varnishes market [1]. These materials are hybrid organo-inorganic composites. Combining the characteristics of both organic and inorganic substances, such structures have great potential in the development of new materials that have a variety of physical, technical and operational characteristics [2]. One of the effective ways to improve the quality of paint and varnishes is to introduce surfactants into their composition [3]. It is obvious that the introduction of surfactants in paint and varnishes changes not only the dispersability of the pigments and fillers included in them, but also the nature of the adsorption and intermolecular interactions in the system. According to the molecular (adsorptive) theory of polymer adhesion, the interactive data, which are manifested in the establishment of the molecular contact of macrochains with the active centers of the substrate and the following formation of adhesion bonds, depends largely on the polarity and flexibility of the polymer chains [4]. The purpose of this work is to study the effect of various surfactants on intermolecular interactions in silicone paint and varnishes.

\section{Experimental}

During the research, the following substunces were used, namely, silicone film-forming (polyphenylsiloxane varnish), toluene solvent (State Standard 14710-78) and three varieties of amine-based surfactants of different molecule-weight composition (Table 1).

$\mathrm{Table} 1$

\section{Surfactants Characteristics}

\begin{tabular}{|c|c|c|c|}
\hline Surfactants name & $\begin{array}{c}\text { Weighted average } \\
\text { molecular mass, a.m.u }\end{array}$ & $\begin{array}{c}\text { Amine number, } \\
\mathrm{mg} \mathrm{HCl} / \mathrm{g}\end{array}$ & Brief Description \\
\hline HMA & 250 & 30 & Mixture of primary and secondary amines \\
\hline CMA & 350 & 32 & Condensation product of vegetable oils with diamines \\
\hline BMA & 600 & 31 & High-molecular amine mixture \\
\hline
\end{tabular}

A viscosimetric method was used to assess the nature and regularities of amines and polyphenylsiloxane structuring in toluene solutions. The dynamic viscosity of the prepared solutions was measured with a capillary viscosimeter $(d=0.56 \mathrm{~mm})$ in a temperature-controlled mode [5].

A low-frequency dielectrometry has been successfully applied to detect the physical grid of intermolecular bonds in the process of its formation [6]. Orientational polarization, as well as deformation, was record- 
ed for the periods of charge and discharge of the capacitance sensor by a stable current in the frequency range of $1-10 \mathrm{kHz}$. The experimental values of the dielectric capacitance $\left(\varepsilon^{\prime}\right)$ and the dielectric loss tangent $(\tan \delta)$ were used to find the dipole-segment loss coefficient $\varepsilon^{\prime \prime}\left(\varepsilon^{\prime \prime}=\dot{\varepsilon} \times \operatorname{tg} \delta\right)$ [4], which usually increases with polarity increase and molecular mobility of the polymers. Considering the fact that the development of structuring processes is accompanied by an increase in the cohesive interaction of molecules, it seemed reasonable to determine the change in this parameter from the results of measuring the solutions surface tension by the method of the greatest pressure of air bubbles (the Rehbinder device) [5]. The volume-surface properties of individual solutions (toluene-additive, toluene-polyphenylsiloxane) and solutions of mixed composition (toluene-polyphenylsiloxane-additive) were established by varying the content of amines and polyphenylsiloxane $\left(0-2 \mathrm{~g} / \mathrm{dm}^{3}\right)$ and $\mathrm{T}(295-313 \mathrm{~K})$.

\section{Results and discussion}

The results of rheological studies of individual solutions are shown in Figure $1 a, b$. The analysis of the change in the relative viscosity of polyphenylsiloxane (PPS) solutions showed (Fig. 1a) that at a constant temperature, as the concentration increases, a linear increase in viscosity is observed. These results are consistent with the literature data [7] and indicate weak intermolecular interactions in PPS solutions. The latter is obviously connected with the special structure of the PPS macromolecules, in which the inorganic chain of silicon and oxygen atoms is surrounded by aryl radicals. The argument for this observation is that for amino derivatives containing amino groups with different degrees of substitution, and at the ends of chains, as well as primary concentrations dependences of the relative viscosity have an entirely different nature and reflect their tendency to associate processes (Fig. 1b). The formation of associated structures judging by the significant deviation from the linear dependence $\eta_{\text {rel. }}=f(C)$ was noted in solutions of all amino derivatives varieties at concentrations above $0.5 \mathrm{~g} / \mathrm{dm}^{3}$; and the association effects increase with the further increase of their concentration in the solution. The viscosity increase at the concentration range of $0.5-2 \mathrm{~g} / \mathrm{dm}^{3}$ corresponds to the molecule-mass ratio of the amino derivatives and increases in the series: BMA $>$ CMA $>$ HMA.
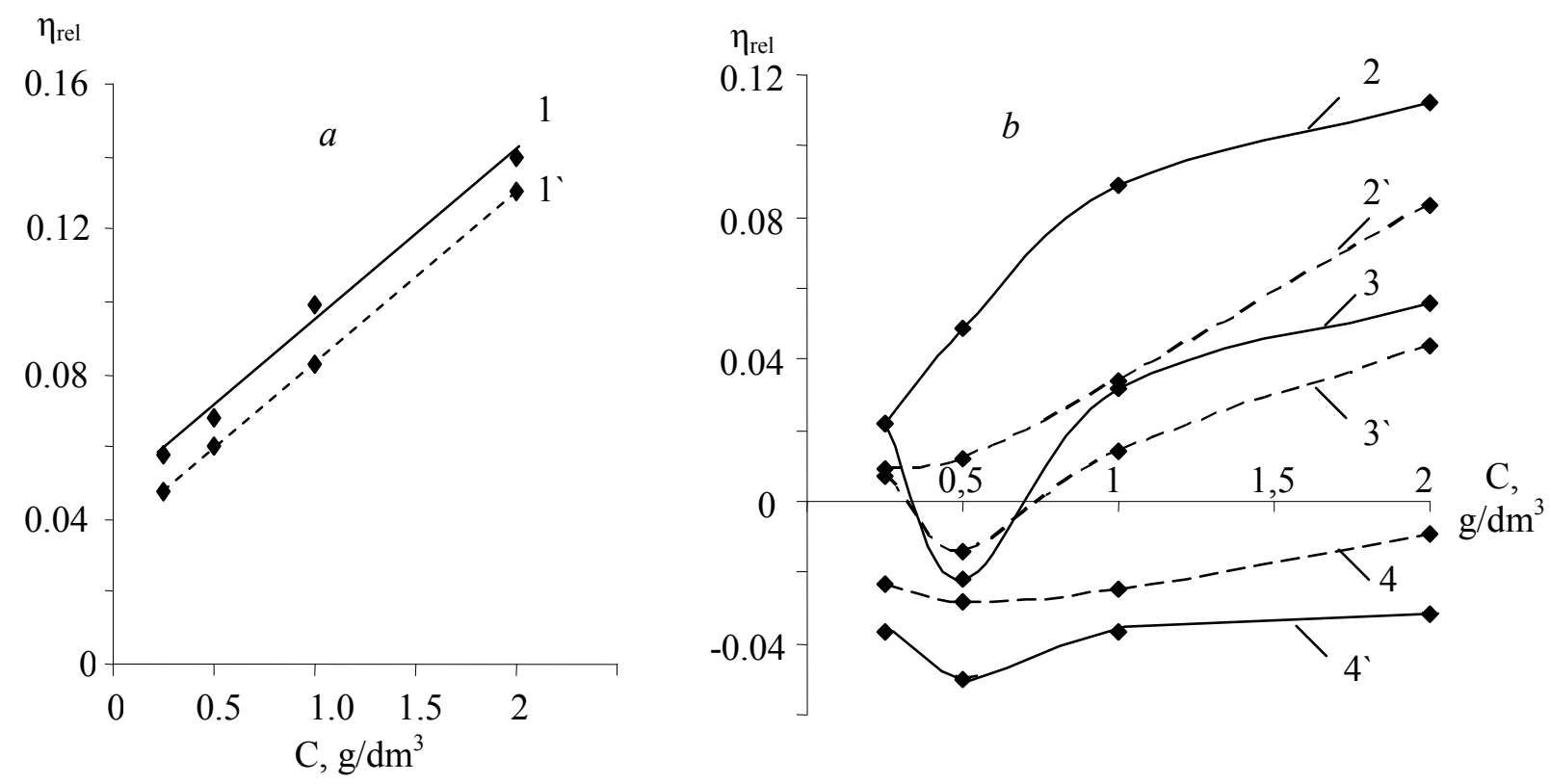

Full line - $298 \mathrm{~K}$; dashed line - $313 \mathrm{~K} ; 1,1^{`}-\mathrm{PPS} ; 2,2^{`}-\mathrm{BMA} ; 3,3^{`}$ - CMA; 4,4 — HMA

Figure 1. Dependence of individual solutions relative viscosity on the concentration of polyphenylsiloxane $(a)$ and amino derivatives $(b)$ at different temperatures

The changes observed in the relative viscosity agree with the surface tension isotherms $(\sigma)$ of the solutions at the interface with air and simultaneously find an explanation from the intermolecular associates formation positions and the localization degree of active functional groups. The features of the amino deriva- 
tives surface activity in solutions under study clearly reflect the extremes, which differ in intensity and width, presented in Figure $2 a, b$.

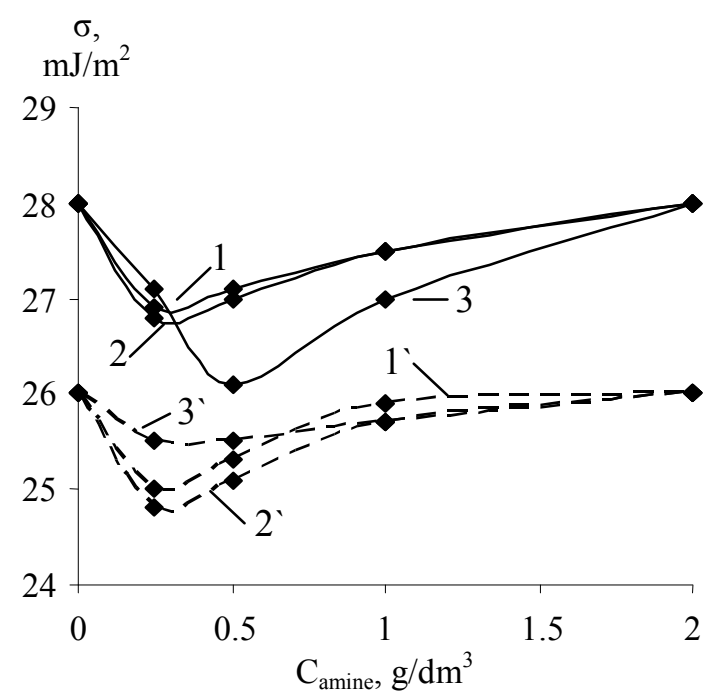

$b$

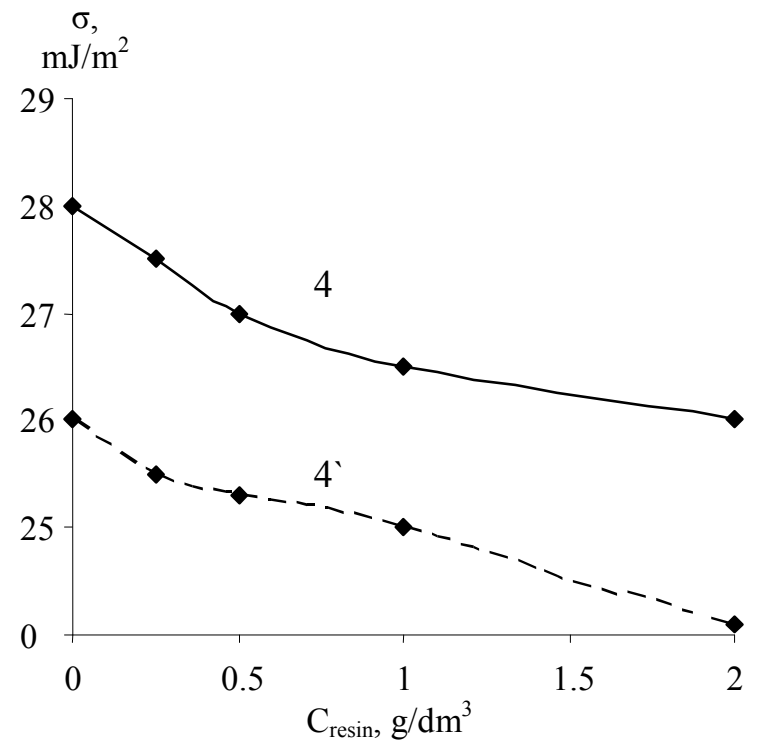

Full line $-298 \mathrm{~K}$; dashed line $-313 \mathrm{~K} ; 1,1^{`}-\mathrm{BMA} ; 2,2^{`}-\mathrm{CMA}$; 3,3`-HMA; $4-\mathrm{PPS}$

Figure 2. Isotherms of individual solutions surface tension at the interface with air

Judging by the surface tension isotherms $(\mathrm{T}=298 \mathrm{~K})$, in the concentration range, when association effects are practically not manifested, the presence of unbound amino derivatives diphilic molecules in the solution has stimulated their concentration in the surface layer, which is confirmed by a decrease in the surface tension values. In this case, two concentration sections can be distinguished, which allow to distinguish between low-molecule and higher-molecule types of amino-derivatives by activity. In solutions with $\mathrm{C} \leq 0.25 \mathrm{~g} / \mathrm{dm}^{3}$, the highest surface activity is characterized by BMA and CMA. The surface-active properties of a lower molecule mass amine species are enhanced in more concentrated solutions. The maximum depression of surface tension $\left(\Delta \sigma=1.9 \mathrm{~mJ} / \mathrm{m}^{2}\right)$ was recorded in HMA solutions at a concentration of $0.5 \mathrm{~g} / \mathrm{dm}^{3}$. As the concentration further increases $\left(C>0.5 \mathrm{~g} / \mathrm{dm}^{3}\right)$ the development of the structure formation processes was accompanied by the spontaneous decrease in the unbound (free) molecules of the amino derivatives and the corresponding continuous deterioration of the surface properties (ascending isotherms). At $\mathrm{C}=2.0 \mathrm{~g} / \mathrm{dm}^{3}$ the surface tension was stabilized in solutions at a level of $28.0 \mathrm{~mJ} / \mathrm{m}^{2}$, which corresponds to the $\sigma$ value of the solvent (toluene). This indicates that there are no more amino derivatives in the surface layer and about complete localization of the functional groups in the internal structure formed in the volume of the intermolecular associates' solution.

It should be noted that the effect of temperature on the indices of $\eta_{\text {rel }}$ and $\sigma$ for the amino derivatives of different molecule-mass composition are not precise. If in the BMA and CMA solutions, at the temperature increase up to $\mathrm{T}=313 \mathrm{~K}$, the relative viscosity values decrease, then in the solutions of the low-molecule variety of amines, their increase was noted, and the main increase was fixed at $\mathrm{C}=0.5 \mathrm{~g} / \mathrm{dm}^{3}$ (Fig. $1 b$ ). The latter may be due to the intensification of solvation processes binding by HMA solvent.

The legality of this justification confirms a sharp deterioration in the HMA surface activity (Fig. 2a); in comparison with $\sigma$ solutions at $\mathrm{T}=298 \mathrm{~K}$, the decrease in the values of surface tension $(\Delta \sigma)$ regarding the solvent (without surfactants) decreased by $2-4$ times and equaled $0.5 \mathrm{~mJ} / \mathrm{m}^{2}$. The depression of surface tension remained at the same level $\left(\Delta \sigma=1.2 \pm 0.2 \mathrm{~mJ} / \mathrm{m}^{2}\right)$ on the contrary to BMA and CMA solutions in the same concentration range.

The surface activity deterioration in the first case and the invariance in the second case exclude the release of amines and, consequently, the destruction of intermolecular structures at $\mathrm{T}=313 \mathrm{~K}$, which would be logical suspect, given the natural increase in the associates thermal motion at temperature increase. At the same time, it is known that the relative viscosity values that exclude the influence of solvent thermal expan- 
sion are determined not only by the number of associates, but also by the steric restrictions they create for the liquid flow.

Summarizing the abovementioned, we can state that for HMA, which is characterized by smaller hydrocarbon radical dimensions, the thermodynamic quality of the solvent improves, which leads to swelling of the associate balls and, thus, to an increase in the relative viscosity., The temperature increase causes an increase in intermolecular interactions within the associates for higher molecular amines, which is accompanied by a decrease of their sizes. The intermolecular structures folded into a tight ball give less resistance to the flow and, as a result, the values of $\eta_{\text {rel }}$ decrease in solutions with $\mathrm{C}=1 \mathrm{~g} / \mathrm{dm}^{3}$ in $2.4-2.6$ times, and at a larger content $\left(\mathrm{C}=2 \mathrm{~g} / \mathrm{dm}^{3}\right)$ in $1.3-1.4$ times.

The results of the viscosimetric analysis are confirmed by the regularities of the surface tension change and for PPS solutions (Fig. 2b), which demonstrate the traditional form of silicone surfactants isotherms not prone to association processes: as the concentration increases from 0 to $2 \mathrm{~g} / \mathrm{dm}^{3}, \sigma$ decreases from 28 to 26 $\mathrm{mJ} / \mathrm{m}^{2}$. The same maximum depression of surface tension $\left(2 \mathrm{~mJ} / \mathrm{m}^{2}\right)$ was observed with increasing temperature $(\mathrm{T}=313 \mathrm{~K})$.

Similar experiments were carried out for solutions with a fixed polyphenylsiloxane concentration $\left(0.5 \mathrm{~g} / \mathrm{dm}^{3}\right)$, but with different contents $\left(\mathrm{C}, \mathrm{g} / \mathrm{dm}^{3}\right)$ of all three amines varieties.

The results of rheological studies and surface tension in mixed composition solutions are presented in Table 2 and Figure $3(a, b, c)$. As a quantitative measure of the processes developed in the volume and on the interphase boundaries, along with the experimental indices $\eta_{\text {rel }}$ and $\sigma$, and their calculated values for an ideal system (in the absence of intermolecular interactions between the mixture components) were also used. In addition, for a comparative evaluation of these processes, the surface tension differential changes were calculated: $\Delta \sigma=\sigma_{\text {exp. }}-\sigma_{\text {calc. }}$ and relative for relative viscosity: $\gamma=\frac{\eta_{\text {rel.exp. }}}{\eta_{\text {rel.calc. }}}$.

$\mathrm{Tab} 1 \mathrm{e} 2$

Relative viscosity calculated and experimental values

\begin{tabular}{|c|c|c|c|c|c|c|}
\hline \multirow{2}{*}{$C, \mathrm{~g} / \mathrm{dm}^{3}$} & \multicolumn{3}{|c|}{$\mathrm{T}=298 \mathrm{~K}$} & \multicolumn{3}{|c|}{$\mathrm{T}=313 \mathrm{~K}$} \\
\hline & $\eta_{\text {rel.exp. }}$ & $\eta_{\text {rel.calc. }}$ & $\gamma$ & $\eta_{\text {rel.exp. }}$ & $\eta_{\text {rel.calc. }}$ & $\gamma$ \\
\hline \multicolumn{7}{|c|}{ HMA } \\
\hline 0.25 & 0.033 & 0.031 & 1.050 & 0.039 & 0.037 & 1.05 \\
\hline 0.5 & 0.063 & 0.018 & 3.500 & 0.048 & 0.032 & 1.50 \\
\hline 1 & 0.077 & 0.031 & 2.480 & 0.056 & 0.035 & 1.60 \\
\hline 2 & 0.089 & 0.036 & 2.470 & 0.083 & 0.051 & 1.63 \\
\hline \multicolumn{7}{|c|}{ CMA } \\
\hline 0.25 & 0.092 & 0.090 & 1.020 & 0.089 & 0.067 & 1.33 \\
\hline 0.5 & 0.078 & 0.066 & 1.180 & 0.073 & 0.046 & 1.59 \\
\hline 1 & 0.089 & 0.100 & 0.890 & 0.112 & 0.074 & 1.51 \\
\hline 2 & 0.107 & 0.124 & 0.860 & 0.131 & 0.104 & 1.86 \\
\hline \multicolumn{7}{|c|}{ BMA } \\
\hline 0.25 & 0.078 & 0.090 & 0.870 & 0.092 & 0.090 & 1.02 \\
\hline 0.5 & 0.102 & 0.118 & 0.860 & 0.078 & 0.066 & 1.18 \\
\hline 1 & 0.121 & 0.157 & 0.770 & 0.089 & 0.100 & 0.89 \\
\hline 2 & 0.140 & 0.187 & 0.770 & 0.107 & 0.124 & 0.86 \\
\hline
\end{tabular}

The data obtained (Table 2) show that in the studied concentration range, there are deviations from the ideal system, i.e. there is an association of molecules of amino derivatives with PPS macromolecules (heteroassociation). It should be noted that the development of heteroassociation processes is much more noticeable, judging by the value of $\gamma$, in solutions with a low molecular mass variety of amines; the greatest change in the relative viscosity (by a factor of 3.5) was noted at $C=0.5 \mathrm{~g} / \mathrm{dm}^{3}$ and $\mathrm{T}=298 \mathrm{~K}$. The formation of intermolecular structures is confirmed by an increase in the cohesive interaction strengthes in HMA solutions and a shift of the surface activity maximum to the region of lower concentrations (Fig. $3 a$ ). 

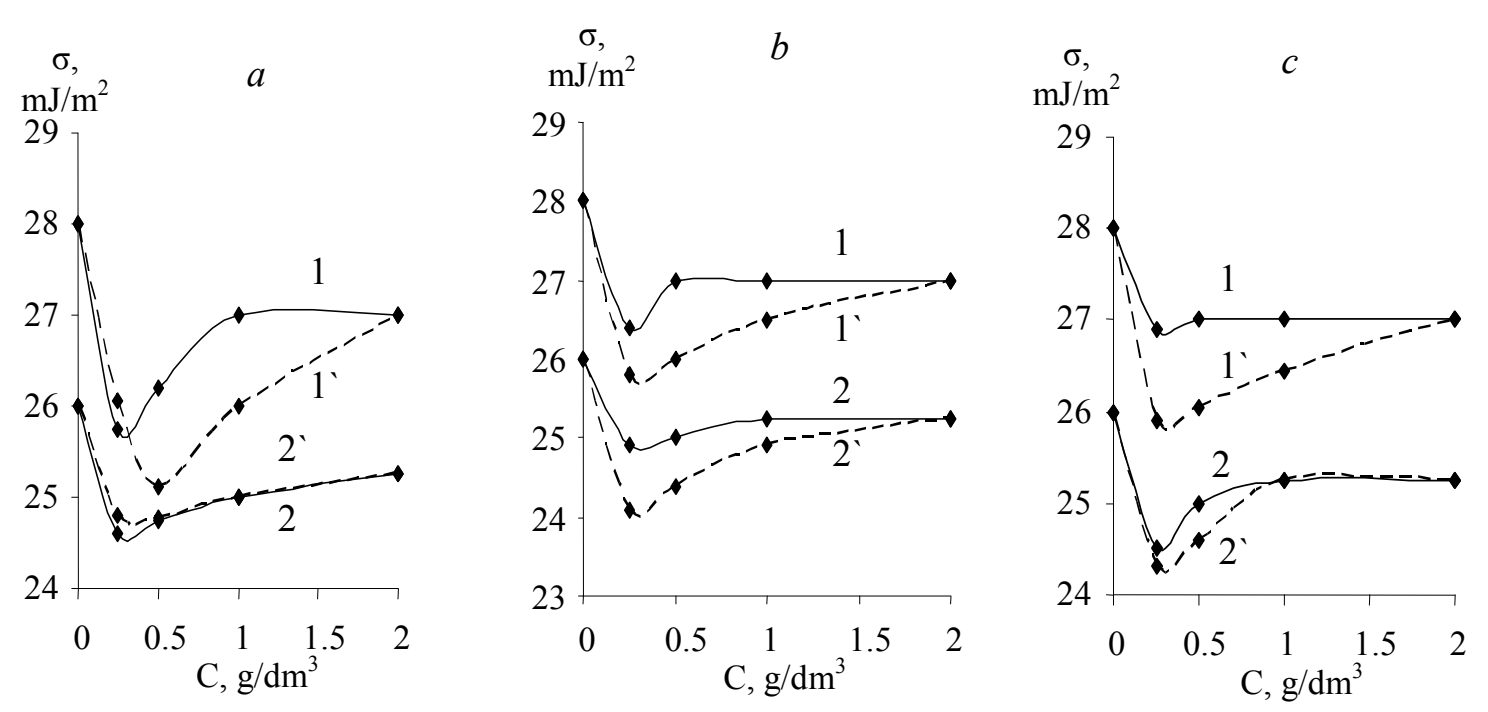

Full line - experimental dependence; dashed line - calculated dependence;

T, K: $1-298 ; 2-313 ; a-\mathrm{HMA} ; b-\mathrm{BMA} ; \mathrm{c}-\mathrm{CMA}$

Figure 3. The effect of the amine-containing surfactants concentration on the surface tension of polyphenylsiloxane solutions $\left(C=0.5 \mathrm{~g} / \mathrm{dm}^{3}\right)$

In a narrow range of concentrations $\left(C \leq 0.25 \mathrm{~g} / \mathrm{dm}^{3}\right)$, a negative deviation of the $\sigma$ values is observed in comparison with the ideal system $\left(-0.5 \mathrm{~mJ} / \mathrm{m}^{2}\right)$, i.e. in the absence of intermolecular interactions in the solution $(\gamma=1.05)$ a synergism is observed in the surface properties of the binary mixture. Outside this interval, a positive deviation of the surface tension experimental values from the additive contribution of the two components (PPS and HMA) was recorded. The maximum intensification of heteroassociation processes at $C=0.5 \mathrm{~g} / \mathrm{dm}^{3}(\gamma=3.5)$ corresponds to the maximum increase in $\sigma\left(\Delta \sigma=+1.03 \mathrm{~mJ} / \mathrm{m}^{2}\right)$, due to the decrease in unbound amines. Stabilization of the structure formation processes $(\gamma=2.47-2.48)$ at $C=1-2 \mathrm{~g} / \mathrm{dm}^{3}$ is consistent with the invariance of the surface tension in this concentration region, which in its values $27.0 \mathrm{~mJ} / \mathrm{m}^{2}$ ) practically coincided with the surface tension of PPS solutions without amines.

The temperature increase (up to $\mathrm{T}=313 \mathrm{~K}$ ) was accompanied by a quantitative destruction of heteroassociates, as indicated by the additive contribution of PPS macromolecules and the released amines (as a result of breaking bonds) in the change in surface tension, and a decrease in the values of $\gamma$ by a factor of $1.5-2$.

The formation of associated structures, judging by the significant increase in $\sigma$, is not excluded in solutions of higher molecular varieties of amines (Fig. $3 b, c$ ). The association processes are developed at lower concentrations in solution in comparison with HMA, which leads to inversion of surface activity. If in toluene individual solutions, as indicated above, with $C=0.25 \mathrm{~g} / \mathrm{dm}^{3}$, the CMA and BMA had the greatest surface activity, then the opposite effect was observed in the joint presence with PPS. The stability of the formed heteroassociates and the variety changes vectoriaty in the $\eta_{\text {rel }}(\gamma<1$ and $\gamma>1)$ in solutions with higher molecule amines indicate differences in the mechanisms of amine association with PPS macromolecules.

The results of dielectrometric measurements (Fig. 4a) suggest that the amino derivatives, depending on individual characteristics (composition, structure, spatial orientation) undergo two types of over- and intramolecular transformations. The first corresponds to the association of HMA molecules with PPS macromolecules, i.e. the formation of peculiar surfactant-polymer complexes. Movable, easily penetrating into the structure of the HMA polymer, when reaching a critical concentration of association $\left(C_{\mathrm{KKA}}>0.25 \mathrm{~g} / \mathrm{dm}^{3}\right)$, being fixed (due to hydrogen and weaker van der Waals forces) along the length of the PPS macromolecule, promotes the expansion of its molecules and the formation of additional bonds between them. As a result, the chain mobility decreases (Fig. $4 a$ ), and the structure strength increases, which reflects the increase in dynamic viscosity (Fig. 4b). Process stabilization at a concentration range of $1-2 \mathrm{~g} / \mathrm{dm}^{3}$ confirms the invariance of the indices $\varepsilon^{\prime \prime}$ and $\eta$. 


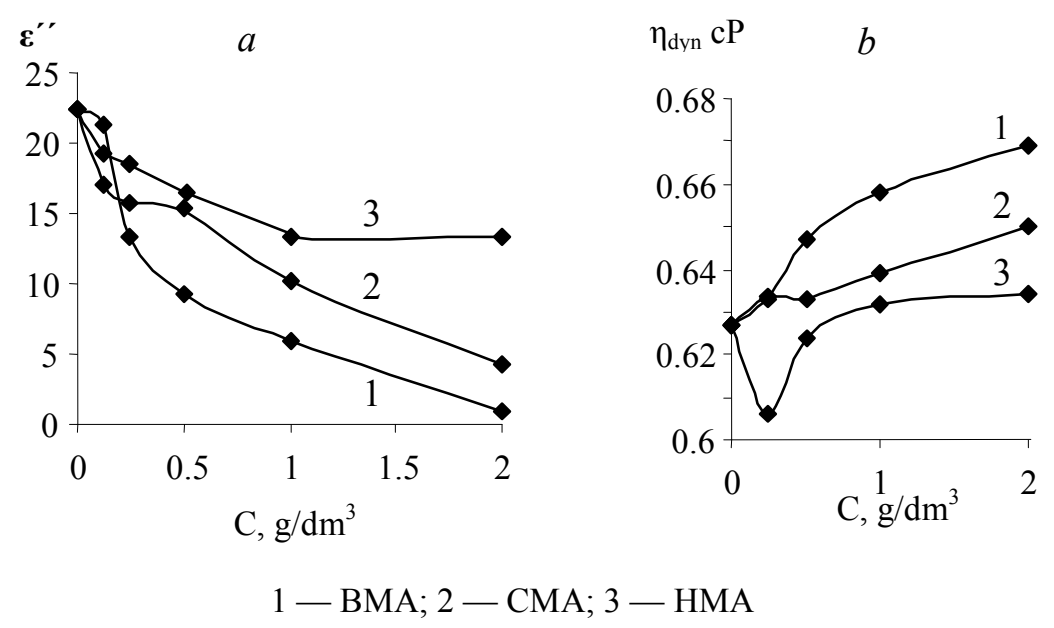

Figure 4. The concentration effect of amine-containing surfactants on the dipole-segmental coefficient $(a)$ and the dynamic viscosity $(b)$ of polyphenylsiloxane solutions $\left(C=0.5 \mathrm{~g} / \mathrm{dm}^{3}\right)$ at $\mathrm{T}=298 \mathrm{~K}$

A significantly longer length of the hydrocarbon radical CMA and BMA will limit their migration in the solution volume, and create steric restrictions for this type of heteroassociation. For CMA and BMA, the interaction between each other (monoassociation) is energetically more advantageous with the simultaneous introduction into their composition of PPS macromolecules (mixed micelles). As the PPS macromolecules are included in the association composition, a continuous decrease in the chain mobility and a synchronous increase in the dynamic viscosity (curves 1 and 2 in Fig. $4 a, b$ ) were recorded.

\section{Conclusions}

Thus, the formation of macromolecular structures is inherent in all three varieties of amines and is substantially enhanced in concentrated solutions. The processes of heteroassociation reduce the amines surface activity and shift it into the region of lower concentrations.

\section{References}

1 Артамонов Г.Л. Силиконовые смолы и модификаторы для индустриальных ЛКМ / Г.Л. Артамонов // Лакокрасочные материалы и их применение. - 2009. - № 2. - С. 32-34.

2 Голубева О.Ю. Гибридные наноструктуры на основе слоистых силикатов и азотсодержащих органических соединений / О.Ю. Голубева // Журнал общей химии. — 2007. — Т. 77, № 2. — С. 246-251.

3 Болатбаев К.Н. Модифицирование композитов поверхностно-активными веществами: монография / К.Н. Болатбаев, А.Н. Дюрягина, К.А. Островной. - Петропавловск: Изд-во СКГУ, 2005. - 184 с.

4 Смехов Ф.М. Повышение адгезионной прочности покрытий путём регулирования полярности и сегментальной подвижности молекул плёнкообразователей / Ф.М. Смехов // Лакокрасочные материалы и их применение. — 1986. — № $1 .-$ C. $23-25$.

5 Малахова А.Я. Практикум по физической и коллоидной химии / А.Я. Малахова. — Минск: Высш. шк., 1974. $366 \mathrm{c}$.

6 Эмме Т. Диэлектрометрические измерения для определения химических структур / Т. Эмме; пер. с нем.; под ред. И.И. Заславского. - М.: Химия, 1967. - 223 с.

7 Фромберг Б.М. Теплостойкие электроизоляционные покрытия / Б.М. Фромберг. - Л.: Государственное энергетическое изд-во, 1959. - 115 с.

\section{А.Н. Дюрягина, А.А. Луценко}

\section{Беткі белсенді заттардың қатысуымен бояу жүйелерін құрылымдауды зерттеу}

Лак-бояу материалдарының сапасын жақсартудың тиімді тәсілдерінің бірі болып олардың құрамына беткі-белсенді заттарды енгізу табылады. Әлбетте, лак-бояу композицияларына беткі-белсенді қоспаларды енгізу оның құрамына кіретін пигменттер мен толықтырғыштардың дисперсиялығын ғана емес, сондай-ақ жүйедегі адсорбциялық және молекулааралық өзара әрекеттесулердің сипатын өзгертеді. Төменжиілікті диэлектрометрияның көмегімен ол қалыптасу үдерісінде молекулааралық 
байланыстардың физикалық торын детекциялау жүргізілді. Вискозиметриялық әдіспен толуол ерітінділерінде аминдер мен полифенилсилоксанды құрылымдастырудың заңдылықтары тағайындалды. Вискозиметриялық талдаудың нәтижелері бойынша полифенилсилоксандар ерітінділері үшін беткі керілістерді өзгертудің заңдылықтары анықталды: концентрация 0 бастап 2 г/дм ${ }^{3}$ дейін ұлғаю шамасына қарай беткі керіліс 28 бастап 26 мДж/м² дейін төмендейді. Реологиялық деректер көрсеткендей, зерттелетін концентрациялардың аймағында мінсіз жүйеден ауытқымалар бар, яғни полифенилсилоксанның макромолекулалары бар амин туындылары молекулаларының ассоциациясы (гетероассоциация) орын алды. Макромолекулалық құрылымдардың түзілуі аминдердің барлық үш түріне тән екені және концентрацияланған ерітінділерді айтарлықтай күшейетіні дәлелденді.

Кілm сөздер: молекулааралық өзара әрекеттесу, вискозиметрия, диэлектрометрия, толуол, қоспалар, аминдер, полифенилсилоксан, беттік керілу, нақты тұтқырлық.

\title{
А.Н. Дюрягина, А.А. Луценко \\ Исследование структурирования лакокрасочных систем в присутствии поверхностно-активных веществ
}

\begin{abstract}
Одним из эффективных способов улучшения качества лакокрасочных материалов является введение в их состав поверхностно-активных веществ. Очевидно, что введение поверхностно-активных добавок в лакокрасочные композиции изменяет не только дисперсность входящих в них пигментов и наполнителей, но и характер адсорбционных и межмолекулярных взаимодействий в системе. С помощью низкочастотной диэлектрометрии было произведено детектирование физической сетки межмолекулярных связей в процессе её формирования. Вискозиметрическим методом установлены закономерности структурирования аминов и полифенилсилоксана в растворах толуола. По результатам вискозиметрического анализа выявлены закономерности изменения поверхностного натяжения для растворов полифенилсилоксанов: по мере увеличения концентрации от 0 до 2 г/дм³ поверхностное натяжение снижается от 28 до 26 мДж/м². Реологические данные показали, что в области исследуемых концентраций существуют отклонения от идеальной системы, т.е. имеет место ассоциация молекул аминопроизводных с макромолекулами полифенилсилоксана (гетероассоциация). Доказано, что образование макромолекулярных структур присуще для всех трёх разновидностей аминов и существенно усиливается в концентрированных растворах.
\end{abstract}

Ключевые слова: кремнийорганические лакокрасочные материалы, межмолекулярные взаимодействия, вискозиметрия, диэлектрометрия, толуол, аддитивы, амины, полифенилсилоксан, поверхностное натяжение, удельная вязкость.

\section{References}

1 Artamonov, G.L. (2009). Silikonovye smoly i modifikatory dlia industrialnykh LKM [Silicone resins and modifiers for industrial paint and varnish paints]. Lakokrasochnye materialy $i$ ikh primenenie - Paint and varnish materials and their application, 2 , 32-34 [in Russian].

2 Golubeva, O.Yu. (2007). Hibridnye nanostruktury na osnove sloistykh silikatov i azotsoderzhashchikh orhanicheskikh soedinenii [Hybrid nanostructures based on layered silicates and nitrogen organic compounds]. Zhurnal obshchei khimii - General Chemistry Journal, 77, 2, 246-251 [in Russian].

3 Bolatbaev, K.N., Dyuryagina, A.N., \& Ostrovnoy, K.A. (2005). Modifitsirovanie kompozitov poverkhnostno-aktivnymi veshchestvami [Modification of composites by surfactants]. Petropavlovsk: Izdatelstvo SKHU [in Russian].

4 Smekhov, F.M. (1986). Povyshenie adhezionnoi prochnosti pokrytii putem rehulirovaniia poliarnosti i sehmentalnoi podvizhnosti molekul plenkoobrazovatelei [Increase of coatings adhesion strength by regulation of polarity and segmental mobility of film-forming molecules]. Lakokrasochnye materialy i ikh primenenie - Paint and varnish materials and their application, 1, 2325 [in Russian].

5 Malahova, A.Ya. (1974). Praktikum po fizicheskoi i kolloidnoi khimii [Workshop on physical and colloid chemistry]. Minsk: Vysshaia shkola [in Russian].

6 Emme, T. (1967). Dielektrometricheskie izmereniia dlia opredeleniia khimicheskikh struktur [Dielectrometric measurements for determining chemical structures]. (I.I. Zaslavskii, Ed.). Moscow: Khimiia [in Russian].

7 Fromberg, B.M. (1959). Teplostoikie elektroizoliatsionnye pokrytiia [Heat-resistant electrical insulating coatings]. Leningrad: Hosudarstvennoe enerheticheskoe izdatelstvo [in Russian]. 